\title{
THE DEVELOPMENT OF FACILITIES AND INFRASTRUCTURE TO SUPPORT SUSTAINABLE COASTAL TOURISM IN BELITUNG REGENCY
}

\author{
Guni Refinda
}

\author{
Master Program of Geography Education Faculty of Social Science, Universitas Negeri Padang \\ refindaguni@ymail.com
}

\begin{abstract}
Tourism development was development that create added value in all aspects of tourism, ranging from infrastructure, attraction of tourism, and other aspects. One of the tourism developments, among others, the development of coastal tourism. The development must be carried sustainable coastal tourism development. Issues contained in the Pacific Islands Coastal Area Tourism was not accommodated well as the existence of its good infrastructure and the absence of supporting public facilities that can support the activities of visitors and tourism are less well-organized system of coastal tourism management by government Belitung regency. Based on this, the need for sustainable development of coastal areas. Facilities that support to achieved all the equipment in order to optimize the area of tourism.
\end{abstract}

Keywords: Development, coastal, tourism, sustainable.

\section{Introduction}

Tourism development is a process of change to create value in all aspect of tourism, starting from facilities, infrastructure, and other aspects. One of tourism sector is coastal tourism. Coastal tourist tourism development itself focuses on the landscape, characteristic of community as the basic of power procession by each region.

The reaction of tourism development can be negative implication in the form of degradation of the environment cause by the exploitation of the resource for tourist activities, so need the management and development of marine tourism sustainable that attention to necessary of the generation while considering the need of the next generation in the future. The concept of sustainable coastal tourism is a tourism that can involve the needs of tourist and tourist destination in the present, while protecting and encouraging similar opportunities in the future.

The sustainable of tourism leads to manage all of resources, so that the needs of economy, social, aesthetic can fulfill and keep the cultural integrity, ecological processes, biological diversity and support the live system. The definition implicitly explained that the sustainable tourism approach not only in sustainable tourism sector but also in the other aspect of life and other social economic sector in an area.

The development of sustainable coastal tourism can also give positive impact for the preservation of the coastal environment. Facilities and infrastructure is essential to support tourism activities. One of them is the approach in the development of tourism facilities and infrastructure, so that the 
effort can use performed optimally. Infrastructure aspect has two sides interest, namely as a means of meeting travels need and as controller in order to maintain the environmental balance. In fact, the development of coastal tourism stills a lot far from the concept of sustainable development of coastal tourism. Which the result not only about reduction in environmental also make uncomfortable to the tourist who come.

Based on the context, sustainable development manage the coastal development and sea define as follows: an effort to use natural resources and environmental services contain in the coastal area and ocean to human (especially stakeholders) such that the level of resource natural utilization and environmental services does not exceed the carrying capacity of the coastal area to provide them ${ }^{1}$. According to Liu et al. ${ }^{2}$ there are four aspect of sustainable development for coastal area:

1. The ecological aspect measured about fishery condition resource, main commodities of fisheries, the diversity of fishery resource, quality of water, diversity of ecosystem and spacious.

2. Economic aspect judge from the number of catches, value of catcher, revenue of net, number of employees, quantity of fishing activities and subsidies in the field for fisheries.

3. Management of social aspect in the coastal area includes the statistics basic of the population and education level. Demographic statistic consists of density of population, sex ratio, dependency rate, and rate of population. The level of education consists of a literacy rate of population age over 5 years.

4. Institutional aspect include several indicators that efficiency management, level of community participation, capacity of community building, institutional sustainability. The concept of sustainable coastal tourism is tourism meet the need of tourist and tourist destination today, while protecting and encouraging similar opportunities in the future.

Sustainable coastal tourism is tourism that meets the needs of the next generation, without compromising the interests of future generations to meet their needs of travelers in enjoying a tourist trip. Facilities and infrastructure is complementary of tourist destination to serve the travelers in enjoying a tourist trip. The tourism business can be define as a business that directly or indirectly provide service to tourist at popular destination, where its extended is dependent on their activities and travel. The facilities are as follows :

a. Accommodation

b. Place to eat and drink

c. Shopping places

d. General facilities at tourist locations.

\footnotetext{
${ }^{1}$ Dahuri R, Rais J, Ginting SP and Sitepu MJ. 2001. Coastal and Marine Resource Management Integrated. Jakarta:PT. Pradnya Paramita.

2 In Darmawan A and Miftahul A. 2012. "Minawisata Development of Small Island to Support Implementation of the Blue Economy". Papers Presented at KONAS VIII Management of Coasts and Small Islands, Mataram October 22 to 24, 2012.
} 
Facilities and infrastructure are essential in a development activity, the provision of facilities and infrastructure according to the needs will be useful in the development activity. In the context of tourism, it should be understood notion that the provision of infrastructure facilities and infrastructure to support sustainable tourism activities. The government of Bangka Belitung province is developing coastal marine tourism potential in Bangka Belitung to raise the tourism sector in the region. This is disclosed by the Governor of Bangka Belitung, Rustam Effendi "the development of nautical tourism should be serious concern, namely by building various facilities and infrastructure in the coastal tourist area, "said Rustam, Tuesday (17/15). The geographical position of Bangka Belitung very strategic because the located in the toll lanes Seafood Indonesia, because it must be used with the best. Bangka Belitung has the characteristics of maritime tourism, in addition to small islands with white sand and beautiful granite rocks. Therefore, the Government of Bangka Belitung province should be set up facilities and supporting infrastructure are required. Such as airports, infrastructure as well as lodging and other means to increase tourist arrivals in the Laskar Pelangi country.

\section{Method}

This research was conducted in Belitung regency, Bangka Belitung Province. The approach used is qualitative, produces descriptive data in the form of words written or spoken, and the behavior of people or society in the area of research ${ }^{3}$. Informants were selected purposively using snowball sampling technique, where the subject (sample) selected earliest appoint someone else who is expected to provide deeper and detailed information ${ }^{4}$. The informants come from the institute of government, youth and people around the coastal areas.

\section{Results and Discussion}

The research concludes that the result of interview and focused of group discussion toward department of tourism, youth and society in Belitung regency on the development of facilities and infrastructure to support sustainable coastal tourism in Belitung regency, namely:

\section{Accommodation}

Existing accommodation in the area can be said still lacked, because of the existing accommodation was far to the tourist attractions are provided. Although some place decent accommodation with provided the facilities. It's also important factor in region developing, because tourist need a place to stay during the trip to be able to rest. Existence facilities would be encouraged tourist to visit and felt enjoy the attractions with a long time.

\footnotetext{
${ }^{3}$ Moleong LJ. 2005. Qualitative Research Methodology. Bandung: PT. Remaja Rodakarya; Nazir, Moh. 2003. Research Method. Jakarta: Ghalia Indonesia.

${ }^{4}$ Sugiyono. 2003. Metode Penelitian Administrasi. Bandung: Alfabeta.
} 


\section{Place for eating and drinking}

The traveler who came to visit an attraction certainly wants to enjoy their trip. So, food and beverage service must support it for tourist who didn't bring lunch. Tourist came to enjoy about the scenery and also special food. Similarly, existing in this area has one beach a set of the movie "lascar pelangi" which became an interest icon in Belitung. Food and beverage facilities existed in this area was still lacked in term of variety, the level of quality, services and other thing that can increased a person's as well as where to eat.

\section{Shopping place}

Shopping was a one of the tourist's activities. In this context, shopping not only about food and drink, but also bought souvenirs typical at tourism area to indicate that tourist ever come and visit this tour. In coastal area of Belitung regency, there is no special souvenir typical, so that tourist cannot spend their money. Though available item for sale such as craft or process of food typical in the coastal area, I the beach of Belitung.

\section{General facilities at tourist location}

The different facilities from other at public facilities in the coastal area of Belitung beach also not all available, such as :
a. Toilets
b. Public place of religion
c. Attraction of tourist location
d. Information and announcement
e. Electricity and telecommunication network

\section{The recommendations to complete infrastructure the coastal tourist in Belitung}

\section{Accommodation}

To make tourist become more interest to visited sustainable needs a comfortable and safe accommodation. As a place to stay during the trip to be able for rest. Existence facilities would be encouraged tourist to visit and felt enjoy the attractions with a long time. Accommodation desire by tourist as well as in addition to safe and make comfortable, such as not far from the tourist areas of cost. This cause by traveler desired the tourist region in order to enjoy the beauty. That is in the region not only during the day but also be done at dusk.

\section{Place to eat and drink}

The commonly tourist needs the clean, safe and comfortable place to eat and drink in coastal area in Belitung beach. For the quality of beverage as sold well. The variety of beverage and food is also preferred to allow tourists to buy according to their own tastes. To increase the traveler interactive, around the site should be provide in regional provide, such Mie in Belitung, the typical coffee of the region and food of other islands. So that, tourist can tastes the typical food of the area. 
This is make tourist become easily and also taking a break tourist able to see even of the region.

\section{Shopping area}

The traveler would be definitely to shop as a souvenirs for the proof that the ever visit the place. This is an area the opportunity to raise local of revenue, introduction an increase the income of local community. The place that provide to shop in coastal areas such Belitung beach in coast cape host in Kelayang. Development is done during the maintaining the comfort and security for buyers later.

\section{General facilities at tourist sites}

The general provide in the coastal areas of Belitung Beach should be increase in quality and quantity. It is important support to activities of the tourist coming. That include of :

a. Parking area

There should be a special place for parking area. So that, the tourist who come o visit the tourist areas can leave their comfort. Parking area must be palnned and mange properly. As the result, the car park sustainable and can provide more income for the region.

b. Toilets

For the constructions of public toilets built some point that must be considerable. So, the travelers become easily to reach the public toilet.

c. Public place of religion

Basically the place was already available. Its' just that the means still much to be repaired. The cleans area as well as the supporting facilities of place, such as clean water and place for religion. Caused that the location of places were not located region was expected to have a place of religion to the beach, so the tourist who come to worship easily.

d. Attraction of tourist location

Its' means that transportation that was convent, safe and cheap. Traveler have no difficulty to reach. Traveler also wants to walk a cozy where all the roads growth the shade plants. There was a place to rest if you feel tired and dispose of waste. As the result, when the tourist was walk during think or eating they will not throw the rubbish and along the way be clean and comfortable.

e. Information and announcement center

The information about Belitung beach in coastal area was expected, not just one at the main to entrance driveway, but there was also announcement or advertisements of coastal areas each strategic in region. Not only about that, had the department also performed in newspapers, radio or magazine. In the tourist area should be available of information and announcement. 
f. Facilities of recreation and playgrounds

The facilities of recreational and playgrounds in Belitung Beach was not exist, allowed to be able built Facilities of recreational and playgrounds. Expected about facilities was attractive and comfortable without damaging the existing attravtion in tourist area. So, traveler have more choice where they want to go and make them have a long time traveled there.

g. The waste

Trash can also increase both the number and quality of trash can. This place also expected to suit the traveler need in supporting tourism activities that they do. The region look not shabby if the garbage has been handled properly and separate between organic and inorganic. On the coast of tourist area of the garbage collected junk cars can be taken within a certain period.

h. Promotion

Promotion was done promote the coastal areas in Belitung Regency Beach was still very low and has not been optimal. In the financial calculated this promotion would be indeed coast a lot of capital but economically as it would be very beneficial and can be sustainable. The campaign needs to be done as to attract investors to be invested in coastal areas in Belitung Regency. The investors' development become better and comfortable to be fulfilled by considered the existing environment.

Eventually the economy would be continued and increased local revenue. Promotion is done can be through social media, radio, television or in written form (banners, newspapers, magazines, etc.). The influence of visitor attraction on the completeness of facilities and infrastructure Marine Tourism Belitung province. Tourist attraction was a formation or activity and related facilities, which can attract tourists or visitors to came to a certain area / specific place. Attraction of visitor was very important to a tourist area. Because, basically, interesting or not interest an tourist area can be seen from the appeal of visitor arrivals in tourist areas.

With so much influence a visitor attraction to the completeness of tourism infrastructure facilities. Because tourists would be less interested in a tourist area if the region does not have a corresponding appeal to the tourist attraction, especially in fulfilling its facilities and infrastructure. For the existing facilities and infrastructure should be built on the coast of Belitung District must match the needs of tourism, so tourists who come impressed and pleased. With so tourists who have come to be back again to enjoy his vacation.

But if the infrastructure is not built in accordance with the expected tourists, travelers likely will not come back for a second time. Because of the appeal of visitors or tourists are not there so that they would choose somewhere more interesting. Therefore, an appeal can be utilized as a tourist attraction. To overcome these conditions, the development of facilities and infrastructure to 
facilitate the tourists, the building must be tailored to the needs of the tourist attraction by considering environmental aspects in order to be sustainable.

\section{Development of Infrastructures to Support the sustainable of coastal tourism.}

\section{Social aspect}

With the number of tourists who came during this indigenous community education was still below the averaged of the impact caused by the activities of the tourism sector in a region of the socio-cultural was felt especially receptive to the influence of the area quickly without any screening of the tourist arrivals. The problems concerned the social impact of tourism on culture has been more likely to occur as a result of socio-cultural change in tourist arrivals. In the development of facilities and infrastructure was an expected to indigenous person can utilize to improve the knowledge, awareness of maintenance, so that the potential and all the facilities and infrastructure supporting sustainable traveled activity.

\section{Economic Aspects}

An economic was in the tourist area of the coast in Belitung still be said not optimal, cause by the people still rely to fishers alone. So that, their income was not to high, although each year has increased. The development of facilities and infrastructure sustainable tourism community was expected to optimize. A way to invite local organization to improve the welfare of society through economic activities such as cooperatives, the development of SMEs in various craft of business, food, beverage, trade, agriculture and others. So, they would have benefited from the development of facilities and infrastructure for tourism. The result that, the economy would be better not only depend on fisher and sustainable for maintaining travel order.

\section{Environmental Aspects}

Tourism activity tends to destroy the natural environment and local culture, therefore, need to be maintained in order to avoid negative impacts with strict supervision and control, observe and reflect local cultural characteristics are typical. Thus, the development of facilities and infrastructure is expected to support coastal tourism and to minimize environmental pollution occurs. Where the environment is initially still not well ordered with the development of facilities and infrastructure will indirectly change be planned. The development will create tourism infrastructure that does not exist in the region to optimize the beach tourism environment to facilitate the activities of tourists who come without damaging the environment.

\section{Conclusion}

Based on the analysis above, show that coastal tourist area in Belitung has a lot of potential, but facilities and infrastructure to support tourism activities still need to improve. The development infrastructure of tourism coastal should be guide by four essential elements that made reference to the theory of sustainability: social 
aspect where the need for increased awareness of maintained, give the knowledge and involve indigenous people in the development of facilities and infrastructure.

To support the activities of coastal tourism that is sustainable, economic aspect of development of infrastructure to support coastal tourism. Indirectly attract tourist to visit invite local to improve the welfare of society through economic activity. Environmental aspect needed awareness that the human resources and natural excessively will disrupt the balance of environmental aspect. Needed the management and maintenance of the coastal tourist area in Belitung beach by combine the cooperation between the governments, private sector, and involving the community. There are four elements that work together in order not lame and cause problems in the next generation. It can be formulated for the government, especially relate with the infrastructure and public participant in the implementation process in the Belitung Beach area.

\section{REFERENCE}

Dahuri R, Rais J, Ginting SP and Sitepu MJ. 2001. Coastal and Marine Resource Management Integrated. Jakarta:PT. Pradnya Paramita.

Darmawan A and Miftahul A. 2012. "Minawisata Development of Small Island to Support Implementation of the Blue Economy". Papers Presented at KONAS VIII Management of Coasts and Small Islands, Mataram October 22 to $24,2012$.

DKP. 2003. Guidelines for Development of Community-Based Marine Tourism in Marine Protected Areas. Department of Marine and Fisheries. Jakarta.

Moleong LJ. 2005. Qualitative Research Methodology. Bandung: PT. Remaja Rodakarya.

Nazir, Moh. 2003. Research Method. Jakarta: Ghalia Indonesia.

Sugiyono. 2003. Metode Penelitian Administrasi. Bandung: Alfabeta. 